\title{
Contributions of PA Taylor, L Mahrt, JJ Finnigan, MR Raupach to Boundary-Layer Meteorology: 1970-2020
}

\author{
John Garratt ${ }^{1} \cdot$ Harindra Fernando ${ }^{2} \cdot$ Bruce Hicks $^{3} \cdot$ James Wilczak $^{4}$ \\ Published online: 27 August 2020 \\ (c) Springer Nature B.V. 2020
}

\section{Introduction}

The following invited summaries give the reader a good overview of each author's sustained effort over the past 50 years. The reader should also ponder the fact that the authors above have published in a range of journals and, with a few exceptions, their contributions referred to below are specific to Boundary-Layer Meteorology alone. We identified four authors: Peter Taylor who first published in Boundary-Layer Meteorology in 1970 (total of 55 publications) and joined the Editorial Board in 1971; Larry Mahrt who first published in the inaugural issue in 1970 (total of 47 publications); and the pair John Finnigan and Mike Raupach, who first published in Boundary-Layer Meteorology in 1976 and 1979 respectively with a combined total of 51 publications, several of which are joint. One other point should give the young scientist pause for reflection: Larry Mahrt and Peter Taylor in particular, being Board members for much of the 50 years, have each reviewed some hundreds of articles submitted to Boundary-Layer Meteorology, an impressive effort in the underpinning of the peer review process.

A little editing has been done to ensure a level of consistency in content (e.g., PhD details, early employment, international activities) and we thank Kathryn Gebauer at the University of Oklahoma for final format editing.

\section{Contributions of Peter Taylor, by Joe Fernando (Notre Dame, Indiana) and Jim Wilczak (Boulder, Colorado)}

Peter Taylor received his $\mathrm{PhD}$ in Applied Mathematics in 1967 at the University of Bristol, UK, and has held a professorial position at York University in Toronto, Canada, for many years. He published an article in the first journal volume (Taylor 1970), was a member of the Editorial Board (1971-95, 2010-20), and was a Co-Editor from 1995 to 2010. His significant

\footnotetext{
John Garratt

jrgarratt@optusnet.com.au

1 CSIRO, Melbourne, Australia

2 University of Notre Dame, Notre Dame, IN, USA

3 Netcorp, Norris, TN, USA

4 NOAA, Boulder, CO, USA
} 
impact on the journal is well evident from the 55 papers he has published in Boundary-Layer Meteorology so far. He was a pivotal organizer of the much celebrated Askervein experiment in the 1980s dealing with flow past a single hill (Taylor and Teunissen 1987). Its benchmark data continue to provide a wellspring of information for boundary-layer meteorologists and wind engineers alike, and was an inspiration for later international projects such as Perdigão (Fernando et al. 2019). Taylor served as Deputy Lead of the Atmospheric Science Theme Group for NASA's Scout program, an initiative for smaller, lower-cost, competed spacecraft. In this role he helped design and evaluate the meteorological instrumentation package on NASA's 2008 Phoenix Mars Lander. In addition to his research, Taylor has been an effective educator and a mentor, and so far has produced a little in excess of 20 PhDs. His former graduate students characterize his mentorship as a thoughtful balance of independence, guidance, and encouragement combined with a warm character and steadfast professionalism.

Taylor's research interests span an impressively wide spectrum of topics:

a. PBL modelling, including model numerics, turbulence parametrizations, model evaluation, and the development of an internal boundary layer due to step-changes in surface roughness or surface heat flux. His theoretical and numerical modelling work demonstrate how sudden changes in roughness and heat flux produce a wide variety of downstream boundary-layer conditions under a range of stability conditions (Taylor 1969, 1970).

b. Ocean-related, primarily model or theoretical investigations of flow over ocean surface waves, but also exploring sediment transport and tidal mixing. In a series of investigations on turbulent airflow over water waves, Gent and Taylor (1976), Taylor and Gent (1978), and Li et al. (2000) delineated useful relationships such as the dependence of drag coefficient on the wave slope and normalized friction velocity, as well as mechanisms of flow separation over wind waves.

c. Model studies of blowing snow-including both dynamical and thermodynamical processes - its parametrization in models, and its impact on visibility. Using numerical and theoretical studies, as well as field experiments using leading-edge radar technologies (Hassan et al. 2017), Taylor made fundamental and practical contributions to the understanding of the characteristics (e.g., particle size distribution, saltation, blowing velocities) and prediction of blowing snow and snow melting (Gordon and Taylor 2009; Gordon et al. 2009).

d. Air quality, including mesoscale meteorological transport of ozone and sulfur processing in clouds. Flagg and Taylor (2011) investigated the characteristics of the urban boundary layer, including their dependence on urban morphology and canopy parameters, and the effects of model grid resolution. Also, his contributions to mesoscale meteorology include studies on surface fronts (Taylor et al. 1993) and convective storm initiation at low-level mesoscale boundaries such as lake breezes (Alexander et al. 2018).

e. Studies on wind energy, including investigations of turbine wake decay and the potential impact of offshore turbines on the mixed layer in lakes. Taylor made key contributions to the understanding of complex terrain flows subjected to varying stability conditions. Particularly noteworthy are his investigations into wind-energy characteristics in complex terrain (Taylor and Teunissen 1987). Salmon and Taylor (2014) carried out in-depth studies on how missing data affect long-term averages, thus helping to quantify uncertainties in wind-farm energy-production estimates. 
f. The meteorology of the Martian atmosphere, based on the analysis of the Phoenix Mars Lander observations, with topics including the sublimation of ice, dust distributions, clouds, and dust devils. Based on short-term pressure drops detected by the Lander, Taylor's group (Ellehoj et al. 2010) inferred the probable passage of convective vortices or dust devils on Mars, and investigated how they are related to the weather at the landing site. Their conclusions were compared with existing theories, adding value to the observations. His work also includes the development of instrumentation for planned or future missions to Mars (Gunnlaugsson et al. 2008).

As a final note on his breadth of scientific interests and contributions to the literature, it is remarkable that one of his highest cited articles falls not within meteorology and geophysics at all, but in biology (Taylor and Williams 1975).

\section{References}

Alexander L, Sills D, Taylor PA (2018) Initiation of convective storms at low-level mesoscale boundaries in southwestern Ontario. Weather Forecast 33(4):583-598

Fernando HJS, Mann J, Laginha Mestre da Palma JM, Lundquist J, Barthelmie R, Pereira MSB, Brown WOJ, Katopodes Chow F, Gerz T, Hocut CM, Klein PM, Leo LS, Matos JC, Oncley SP, Pryor SC, Bariteau L, Bell TM, Bodini N, Carney MB, Courtney M, Creegan E, Dimitrova R, Gomes S, Hagen M, Hyde O, Kigle S, Krishnamurthy R, Lopes JC, Mazzaro L, Neher JMT, Menke R, Murphy P, Oswald L, Otarola-Bustos S, Pattantyus AK, Rodrigues C, Schady A, Sirin N, Spuler S, Svensson E, Tomaszewski J, Turner DD, van Veen L, Vasiljević N, Vassallo D, Voss S, Wildmann N, Wang Y (2019) The Perdigão: Peering into microscale details of mountain winds. Bull Amer Meteorol Soc 100(5):799-819

Flagg DD, Taylor PA (2011) Sensitivity of mesoscale model urban boundary layer meteorology to urban morphology. Atmos Chem Phys 11:2951-2972

Gent PR, Taylor PA (1976) A numerical model of the air flow above water waves. J Fluid Mech 77(1): 105-128

Gordon M, Taylor PA (2009) Measurements of blowing snow, part I: Particle size distribution, velocity, number and mass flux at Churchill, Manitoba, Canada. Cold Reg Sci Technol 55:63-74

Gordon M, Savelyev SA, Taylor PA (2009) Measurements of blowing snow, part II: saltation height and mass density profiles at Franklin Bay, NWT, Canada. Cold Reg Sci Technol 55:75-85

Gunnlaugsson HP, Holstein-Rathlou C, Merrison JP, Jensen SK, Lange CF, Larsen SE, Madsen MB, Nørnberg P, Bechtold H, Hald E, Iversen JJ (2008) Telltale wind indicator for the Mars Phoenix lander. J Geophys Res: Planets 113(E3)

Ellehoj MD, Gunnlaugsson HP, Taylor PA, Kahanpää H, Bean KM, Cantor BA, Gheynani BT, Drube L, Fisher D, Harri AM, Holstein-Rathlou C (2010) Convective vortices and dust devils at the Phoenix Mars mission landing site. J Geophys Res: Planets, 115(E4)

Hassan D, Taylor PA, Isaac G (2017) Snowfall rate estimation using c-band polarimetric radars. Meteorol Appl 24(1):142-156

Li PY, Xu D, Taylor PA (2000) [see BLM publication list]

Salmon J and Taylor PA (2014) Errors and uncertainties associated with missing wind data and short records. Wind Energy 17:1111-1118

Taylor PA (1969) On wind and shear stress profiles above a change in surface roughness. Q J R Meteorol Soc 95:77-91

Taylor PA (1970) [see BLM publication list] 
Taylor PA, leB Williams PJ (1975) Theoretical studies on the coexistence of competing species under continuous-flow conditions. Can J Microbiol 21:90-98

Taylor PA, Teunissen HW (1987) [see BLM publication list]

Taylor PA, Gent PR (1978) A numerical investigation of variations in the drag coefficient for air flow above water waves. Q J R Meteorol Soc 104:979-988

Taylor PA, Salmon JR, Stewart RE (1993) [see BLM publication list]

\section{Contributions of Larry Mahrt, by Bruce Hicks (Norris, Tennessee)}

Larry Mahrt obtained his $\mathrm{PhD}$ in Meteorology at the University of Wisconsin, USA, in 1972. After completing a postdoctoral fellowship at the National Center for Atmospheric Research, he became a faculty member in the Atmospheric Sciences Department at Oregon State University. During 2004 he moved to North-West Research Associates and his research started along new paths. His research interests were often taken up as the result of extended visits to institutes in Europe. He published his first Boundary-Layer Meteorology article in the journal's first issue (Mahrt and Scherdtfeger 1970). During the early part of his career his research emphasized numerical modelling, but it shifted to observational work in the 1980s. Since 2000, much of his work has concentrated on the stable boundary layer (SBL) in terms of turbulence and non-turbulent small-scale motions. In addition to boundary-layer turbulence, his work has included the transfer of heat and moisture within the soil, subcanopy transfer, transpiration, and snow processes. He has participated in a number of field programs, in a few as principal investigator, including the Hydrologic Atmospheric Pilot Experiment: Modelisation du Bilan Hydrique (HAPEX MOBILY, France, 1986), Fluxes over Snow Surfaces (FLOSS, Colorado, USA, 2000-2002), and the Shallow Cold Pool Experiment (Colorado, USA, 2012).

His work on the stable boundary layer deserves special mention, particularly regarding turbulence intermittency. There is a long history on nocturnal turbulence intermittency in SBL flow over land. Munn (1966) demonstrated that such sporadic bursts of turbulence were common, but it was Mahrt et al. (1979) who injected some consideration of the applicability or otherwise of Monin-Obukhov similarity theory (MOST). A subsequent series of articles served to return the intermittency issue to a central position in today's science. The new interest arose, in part, when data from the Microfronts project (Howell and Sun 1999) were used by Mahrt et al. (1998) to draw attention to the role of nocturnal turbulence intermittency in the very stable boundary layer. Subsequently, Mahrt (1999) reviewed current understanding, concluding that conventional flux-gradient approaches are confined to unstable and weakly stable stratification, whereas for the very stable case all bets are off. A series of articles followed (e.g., Mahrt et al. 1998, 2013; Mahrt and Vickers 2006) clarifying that, whereas the criteria distinguishing different nocturnal intermittency regimes were originally based on the stability parameter $\zeta$ (in line with MOST), later studies departed from MOST. It was the CASES-99 study (Poulos et al. 2002) that bridged the gap between the SBL and the general boundary-layer aspects of the observed phenomenon. The subsequent series of CASES-99 articles (starting with Sun et al. 2002) dominated much of the literature discussion of the following decade, although well supported by data from other locations (e.g., Ohya et al. 2008; Ansorge and Mellado 2014; Cava et al. 2019). In his pursuit of the understanding of the SBL and its turbulence characteristics, Larry has combined the CASES experience with extensive studies of drainage flows (Mahrt et al. 2001; Soler et al. 2002) and locally influenced wind-field variations (Mahrt 2008; 2009). Implications regarding heat exchange, dispersion, 
and mixing in general (Mahrt and Vickers 2006; Mahrt 2017a, b) have also been explored. In a recent presentation, Mahrt et al. (2020) concentrate on three experiments designed to elucidate specific aspects of the mechanisms of the intermittency. Two studies were of flow within clearly defined valleys. The third was a subset of CASES-99, focused on observations made very close to the surface. It goes without saying that the intermittency phenomenon leads to obvious problems for flux-gradient formulations (Mahrt 2007; 2010; 2011).

Major discussions of the relevant science have been provided within the pages of Boundary-Layer Meteorology, and Larry Mahrt has been a major participant (e.g., Mahrt et al. 1979; Mahrt 1999). Elsewhere, he has provided an extensive review of the current understanding of the nocturnal terrestrial atmosphere (Mahrt 2014). It must be hoped that the science will continue to be explored, and that the consequences of atmospheric fluctuations lying outside the universe of spectral uniformity will prove to be describable in a manner permitting adjustment to numerical models of the planetary boundary layer.

\section{References}

Ansorge C, Mellado J (2014) Global intermittency and collapsing turbulence in a stratified planetary boundary layer. Boundary-Layer Meteorol 153:89-116

Cava D, Mortarini L Giostra U, Acevedo O, Katul G (2019) Submeso motions and intermittent turbulence across a nocturnal low-level jet: a self-organized criticality analogy. Boundary-Layer Meteorol 172:17-43

Howell JF, Sun J (1999) Surface-layer fluxes in stable conditions. Boundary-Layer Meteorol 90:495-520

Mahrt L (1999) [see BLM publication list]

Mahrt L (2007) [see BLM publication list]

Mahrt L (2008) [see BLM publication list]

Mahrt L (2009) [see BLM publication list]

Mahrt L (2010) [see BLM publication list]

Mahrt L (2011) [see BLM publication list]

Mahrt L (2014) Stably stratified atmospheric boundary layers. Ann Rev Fluid Mech 46:23-45

Mahrt L (2017a) [see BLM publication list]

Mahrt L (2017b) [see BLM publication list]

Mahrt L, Heald RC, Lenshow DH, Stankov BB, Troen LB (1979) [see BLM publication list]

Mahrt L, Pfister L, Thomas CK (2020) [see BLM publication list]

Mahrt LJ, Schwerdtfeger W (1970) [see BLM publication list]

Mahrt L, Sun J, Blumen W, Delany T, Oncley S (1998) [see BLM publication list]

Mahrt L, Thomas C, Richardson S, Seaman N, Stauffer D, Zeeman M (2013) [see BLM publication list] 
Mahrt L, Vickers D (2006) [see BLM publication list]

Mahrt L, Vickers R, Nakamura R, Sun J, Burns S, Lenschow D, Soler M (2001) [see BLM publication list]

Munn RE (1966) Descriptive micrometeorology. Academic Press, New York.

Ohya Y, Nakamura R, Uchida T (2008) Intermittent bursting of turbulence in a stable boundary layer with low-level jet. Boundary-Layer Meteorol 126(3):24-263

Poulos GS, Blumen W, Fritts DC, Lundquist JK, Sun J, Burns SP, Nappo C, Banta R, Newsom R, Cuxart J, Terradellas E, Balsley B, Jensen M (2002) CASES-99: A Comprehensive Investigation of the Stable Nocturnal Boundary Layer. Bull Amer Meteorol Soc 83:555-581

Soler M, Infante C, Buenestato P, Mahrt L (2002) [see BLM publication list]

Sun J, Burns S, Lenschow D, Banta R, Newsom R, Coulter R, Frasier S, Ince T, Nappo C, Cuxart J, Blumen W, Lee X, Hu X-Z (2002) Intermittent turbulence associated with a density current passage in the stable boundary layer. Boundary-Layer Meteorol 106:199-219

\section{Contributions of John Finnigan and Mike Raupach, by John Garratt (Melbourne, Australia)}

John Finnigan received his Ph.D. in 1978 at the Australian National University, Canberra, and Mike Raupach in 1976 at Flinders University, Adelaide, joining the CSIRO environmental mechanics group in Canberra in 1972 and 1978, respectively, when John Philip was Chief. Each brought his impressive mathematical and analytical skills, together with physical insights, to a range of boundary-layer problems, focusing initially on turbulent airflow above and within aerodynamically rough surfaces, both in the wind tunnel and in the natural world but later extending to larger scales. All in all, they contributed to 45 publications in Boundary-Layer Meteorology - Raupach authored 25 articles, Finnigan 26, most as single authors, and several together. Their earliest articles in Boundary-Layer Meteorology are dated 1976 for Finnigan and 1979 for Raupach. Sadly, Raupach died in 2015, whilst Finnigan continues to work and publish to this day.

John Finnigan's main contributions relate to: (i) the description of the mean and turbulent properties of airflow above and within natural plant canopies (a series of seven papers between 1978 and 2000, some with co-authors Y Brunet, PJ Mulhearn, and RH Shaw); (ii) the development of the theory of flow over low hills covered with tall canopies (with SE Belcher and IH Harman); (iii) a unified theory for flow in the canopy layer and in the roughness sublayer (RSL, several papers between 2007 and 2016, with I Harman as senior author); (iv) the clarification of the relationship between the parameters governing the 'big-leaf' description of vegetation-atmosphere exchange, based on the Penman-Monteith or Combination equation, and the physiological parameters that can be measured at leaf level; (v) a two-paper analysis of long-term flux measurement techniques (Finnigan et al. 2003; Finnigan 2004). At larger scales, Finnigan developed theory and observational techniques describing waveturbulence interaction in the boundary layer (with F Einaudi) and collaborated with Raupach on the development of thermodynamically-based averaging principles for surfaces covered with heterogeneous vegetation or topography.

Mike Raupach's main contributions relate to: (i) scalar dispersion within plant canopies (several papers in the 1980s, with BJ Legg); (ii) turbulent properties of airflow within and above plant canopies; (iii) the RSL (several during the period 1979 to 1992) and drag characteristics of rough surfaces, especially as they affect wind erosion (several between 1992 
and 2006). He also steadily moved his attention from the details of turbulent exchange near the surface to larger scales, first answering open questions on the nature of whole-of-PBL feedbacks on surface evaporation by the rigorous application of thermodynamic principles. With these principles firmly established, he became a pioneer in quantifying the global carbon and energy cycles at continental to global scales, eventually leading the Global Carbon Project as its inaugural co-chair.

Two major contributions concerned (i) airflow within and above natural plant canopies, and (ii) the elucidation of the properties of the RSL, leading to analytical expressions for key aerodynamic properties of rough surfaces, such as the roughness length and zero-plane displacement, as functions of surface geometry and of atmospheric stability.

The breakdown of the neutral logarithmic wind law, and in flux-profile relations generally, above tall crops and forests became apparent from 1975 onwards (e.g., Thom et al. 1975; Garratt 1978; Raupach 1979). The term "roughness sublayer" was almost certainly first used by Raupach et al. (1980) as part of a major wind-tunnel study on the breakdown of the log law close to a rough surface. These authors and Raupach (1992) made the first serious attempts at determining analytical expressions for the depth of the RSL and for the profile influence function that described the deviation of the actual RSL profile from the log profile. Some years later this early work was expanded to a unified theory of flow in the canopy layer and in the RSL above, both for wind speed and scalar concentration (Harman and Finnigan 2007, 2008). The key step involved a coupling between the canopy and surfacelayer flows using a mixing-layer analogy for the flow at the interface, viz., the canopy top. The approach envisaged the RSL as characterized by coherent eddies, with extra mixing generated by the inviscid instability mechanism acting at the canopy top (Raupach et al. 1996). It follows that the additional relevant length scale that describes the profile influence function is $U /(d U / d z)$ at the inflection point (canopy top). The resulting profile forms, for chosen canopy variables and stability, were compared favourably with observed wind-speed, temperature and humidity profiles within and above several forest canopies, and the resulting theory has now been successfully incorporated in several widely used boundary-layer and climate models.

Finnigan's Ph.D. work in 1979 applied then novel conditional sampling techniques to a canopy of natural wheat and a wind-tunnel model, both of which exhibited the phenomenon of honami or coherent waving. This work, which was soon supported by other researchers-notably RH Shaw-showed that momentum and scalar transport to and from canopies was dominated by eddies of whole canopy scale, which manifest themselves as intermittent 'sweeps' and 'ejections'. This was in contrast to the earlier view that canopy turbulence was dominated by leaf wakes. After Raupach joined the CSIRO group in 1978, the history of the next few years could be summarized as the search for the origin of these large coherent eddies. This was a fruitful period, demonstrating that large eddies can induce counter-gradient diffusion in canopies, an observation that was elegantly explained by Raupach's localized near-field theory and eventually led to a complete description of the nature of canopy eddies when the flow is shear dominated (Finnigan et al. 2009). This understanding in turn indicated the use of the shear instability parameter $U /(d U / d z)$ as the extra length scale in a unified model of canopy and RSL flow noted above.

Finnigan and Raupach played major roles in the overall research activity of the CSIRO group, and each had a major involvement in the atmospheric sciences at the international level.

\section{References}

Finnigan JJ (2004) [see BLM publication list] 
Finnigan JJ, Clement R, Malhi Y, Leuning R, Cleugh HA (2003) [see BLM publication list]

Finnigan JJ, Shaw RH, Patton EG (2009) Turbulence Structure above vegetation canopies. J Fluid Mech 637:387-424

Garratt JR (1978) Flux profile relations above tall vegetation. Q J R Meteorol Soc 104:199-211

Harman IN, Finnigan, JJ (2007) [see BLM publication list]

Harman IN, Finnigan JJ (2008) [see BLM publication list]

Raupach MR (1979) [see BLM publication list]

Raupach MR (1992) [see BLM publication list]

Raupach MR, Thom AS, Edwards I (1980) [see BLM publication list]

Raupach MR, Finnigan JJ, Brunet Y (1996) [see BLM publication list]

Thom AS, Stewart JB, Oliver HR, Gash JHC (1975) Comparison of aerodynamic and energy budget estimates of fluxes over a pine forest. Q J R Meteorol Soc 101:93-105

\section{Full list of BLM publications for PA Taylor, L Mahrt, JJ Finnigan, and MR Raupach}

\section{PA Taylor}

Taylor PA (1970) A model of airflow above changes in surface heat flux, temperature and roughness for neutral and unstable conditions. Boundary-Layer Meteorol 1(1):18-39

Delage Y, Taylor PA (1970) Numerical studies of heat island circulations. Boundary-Layer Meteorol 1(2):20 1-226

Taylor PA (1971) Airflow above changes in surface heat flux, temperature and roughness; an extension to include the stable case. Boundary-Layer Meteorol 1(4):474-497

Taylor PA, Delage Y (1971) A note on finite-difference schemes for the surface and planetary boundary layers. Boundary-Layer Meteorol 2(1):108-12 1

Taylor PA (1972) Wind profile development above a locally adjusted sea surface. Boundary-Layer Meteorol 2(3):381-389

Taylor PA, Gent PR (1974) A model of atmospheric boundary-layer flow above an isolated, two dimensional "hill"; an example of flow above gentle topography. Boundary-Layer Meteorol 7(1-4):349-362

Gent PR, Taylor PA (1977) A note on 'separation' over short wind waves. Boundary-Layer Meteorol 11(1):65-87

Taylor PA (1977) Some numerical studies of surface boundary-layer flow above gentle topography. Boundary-Layer Meteorol 11(4):439-465

Taylor PA (1977) Numerical studies of neutrally stratified planetary boundary-layer flow above gentle topography l: two-dimensional cases. Boundary-Layer Meteorol 12(1):37-60 Peterson EW, Taylor PA, Højstrup J, Jensen NO, Kristensen L, Petersen EL (1980) Ris 1978: Further investigations into the effects of local terrain irregularities on tower-measured wind profiles. Boundary-Layer Meteorol 19(3):303-313

Taylor PA, Walmsley JL (1981) Estimates of wind speed perturbation in boundary-layer flow over isolated low hills—a challenge. Boundary Layer Meteorol 20(2):253-257

Walmsley JL, Taylor PA (1981) Estimates of wind speed perturbation in boundary-layer flow over isolated hills—solutions. Boundary-Layer Meteorol 20(3):391-395

Walmsley JL, Salmon JR, Taylor PA (1982) On the application of a model of boundarylayer flow over low hills to real terrain. Boundary-Layer Meteorol 23(1):17-46 
Taylor PA, Walmsley JL, Salmon JR (1983) A simple model of neutrally stratified boundary-layer flow over real terrain incorporating wavenumber-dependent scaling. Boundary-Layer Meteorol 26(2):169-189

Taylor PA (1983) On wakes and the net forces produced by surface-mounted obstacles in neutrally stratified atmospheric boundary-layers. Boundary-Layer Meteorol 27(4):393-412

Walmsley JL, Taylor PA, Keith T (1986) A simple model of neutrally stratified boundarylayer flow over complex terrain with surface roughness modulations (MS3DJH/3R). Boundary-Layer Meteorol 36(1-2):157-186

Beljaars ACM, Walmsley JL, Taylor PA (1987) A mixed spectral finite-difference model for neutrally stratified boundary-layer flow over roughness changes and topography. Boundary-Layer Meteorol 38(3):273-303

Taylor PA, Teunissen HW (1987) The Askervein Hill project: overview and background data. Boundary-Layer Meteorol 39(1-2):15-39

Taylor PA, Mason PJ, Bradley, EF (1987) Boundary-layer flow over low hills. BoundaryLayer Meteorol 39(1-2):107-132

Raithby GD, Stubley GD, and Taylor PA (1987) The Askervein Hill project: a finite control volume model prediction of three-dimensional flows over the hill. Boundary-Layer Meteorol 39(3): 247-267

Taylor PA (1987) Comments and further analysis on the effective roughness lengths for use in numerical three-dimensional models, Boundary-Layer Meteorol 39(4):403-418

Beljaars ACM, Walmsley JL, Taylor PA (1987) Modelling of turbulence over low hills and varying surface roughness. Boundary-Layer Meteorol 41(1-4):203-215

Mickle RE, Cook NJ, Hoff AM, Jensen NO, Salmon JR, Taylor PA, Tetzlaff G, Teunissen HW (1988) The Askervein Hill project: vertical profiles of wind and turbulence. BoundaryLayer Meteorol 43(1-2):143-169

Salmon JR, Bowen AJ, Hoff AM, Johnson R, Mickle RE, Taylor PA, Tetzlaff G, Walmsley JL (1988) The Askervein Hill project: mean wind variations at fixed heights above ground. Boundary-Layer Meteorol 43(3):247-271

Salmon JR, Teunissen HW, Mickle RE, Taylor PA (1988) The Kettles Hill project: field observations, wind-tunnel simulations and numerical model predictions for flow over a low hill. Boundary-Layer Meteorol 43(4):309-343

Taylor PA, Sykes RI, Mason PJ (1989) On the parameterization of drag over smallscale topography in neutrally stratified boundary-layer flow. Boundary-Layer Meteorol 48(4):409-422

Taylor PA (1989) Comments on: 'Elimination of spurious inertial oscillations in boundary-layer models with time-dependent geostrophic winds.' Boundary-Layer Meteorol 48(4):445-446

Beljaars ACM, Taylor PA (1989) On the inner-layer scale height of boundary-layer flow over low hills. Boundary-Layer Meteorol 49(4):433-438

Xu D, Taylor PA (1991) A note on the mixed spectral finite-difference model equations. Boundary-Layer Meteorol 56(1-2):205-206

Xu D, Taylor PA (1992) A non-linear extension of the mixed spectral finite difference model for neutrally stratified turbulent flow over topography. Boundary-Layer Meteorol 59(1-2):177-186

Taylor PA, Salmon JR, Stewart RE (1993) Mesoscale observations of surface fronts and low-pressure centres in Canadian East Coast winter storms. Boundary-Layer Meteorol 64(1):15-54 
Ayotte KW, Xu D, Taylor PA (1994) The impact of turbulence closure schemes on predictions of the mixed spectral finite-difference model for flow over topography. Boundary-Layer Meteorol. 68(1):1-33

Kwan J, Taylor PA (1994) On gas fluxes from small lakes and ponds. Boundary-Layer Meteorol 68(4): 339-356

Xu D, Ayotte KW, Taylor PA (1994) Development of the non-linear mixed spectral finite difference model for turbulent boundary-layer flow over topography. Boundary-Layer Meteorol 70(4):341-367

$\mathrm{Xu}$ D, Taylor PA (1995) A note on the constants used in $\mathrm{E}-\varepsilon-\tau$ turbulence closure. Boundary-Layer Meteorol 72(1-2):205-211

Taylor PA, Thomas M, Truhlar ED, Whelpdale D (1996) R. E. (Ted) Munn-Founding Editor; a mini-biography. Boundary-Layer Meteorol 78(1-2):3-8

Walmsley JL, Taylor PA (1996) Boundary-layer flow over topography: impacts of the Askervein Study. Boundary-Layer Meteorol 78(3-4):291-320

Xu D, Taylor PA (1997) An E- $\varepsilon-l$ turbulence closure scheme for planetary boundary-layer models: the neutrally stratified case. Boundary-Layer Meteorol, 84(2):247-266

Xu D, Taylor PA (1997) On turbulence closure constants for atmospheric boundary-layer modelling: neutral stratification. Boundary-Layer Meteorol 84(2):267-287

Taylor PA (1998) The thermodynamic effects of sublimating, blowing snow in the atmospheric boundary layer. Boundary-Layer Meteorol 89(2):251-283

Pagowski M, Taylor PA (1998) Fronts and the boundary layer-some numerical studies. Boundary-Layer Meteorol 89(3):469-506

Li PY, Xu D, Taylor PA (2000) Numerical modelling of turbulent airflow over water waves. Boundary-Layer Meteorol 95(3):397-425

Xiao J, Bintanja R, Déry SJ, Mann GW, Taylor PA (2000) An intercomparison among four models of blowing snow. Boundary-Layer Meteorol 97(1):109-135

Mengesha YG, Taylor PA, Lenschow, DH (2001) Boundary-layer turbulence over the Nebraska Sandhills. Boundary-Layer Meteorol 100(1):3-46

Savelyev SA, Taylor PA (2001) Notes on an internal boundary-layer height formula. Boundary-Layer Meteorol 101(2):293-301

Xiao J, Taylor PA (2002) On equilibrium profiles of suspended particles. Boundary-Layer Meteorol 105(3):471-482

Weng W, Taylor PA (2003) On modelling the one-dimensional atmospheric boundary layer, Boundary-Layer Meteorol 107(2):371-400

Savelyev S, Taylor PA (2005) Internal boundary layers: I. height formulae for neutral and diabatic flows. Boundary-Layer Meteorol 115(1):1-25

Li PY, Taylor PA (2005) Three-dimensional Lagrangian simulation of suspended particles in the neutrally stratified atmospheric surface layer. Boundary-Layer Meteorol 116(2):301-311

Cuxart J, Holtslag AAM, Beare RJ, Bazile E, Beljaars A, Cheng A, Conangla L, Ek M, Freedman F, Hamdi R, Kerstein A, Kitagawa H, Lenderink G, Lewellen D, Mailhot J, Mauritsen T, Perov V, Schayes G, Steeneveld GJ, Svensson G, Taylor P, Weng W, Wunsch S, Xu KM (2006) Single-column model intercomparison for a stably stratified atmospheric boundary layer. Boundary-Layer Meteorol 118(2):273-303

Weng W, Taylor PA (2006) Modelling the one-dimensional stable boundary layer with an $E$ - $l$ turbulence closure scheme. Boundary-Layer Meteorol 118(2):305-323

Taylor PA, Li PY, Michelangeli DV, Pathak J, Weng W (2007) Modelling dust distributions in the atmospheric boundary layer on Mars. Boundary-Layer Meteorol 125(2):305-328 
Gordon M, Taylor PA (2009) The electric field during blowing snow. Boundary-Layer Meteorol 130(1):97-115

Gheynani BT, Taylor PA (2010) Large-eddy simulations of vertical vortex formation in terrestrial and Martian convective boundary layers. Boundary-Layer Meteorol 137(2):223-235

Xiao Yu, Weng W, Taylor PA, Liang D (2011) Relaxation factor effects in the non-linear mixed spectral finite difference model of flow over topographic features. Boundary-Layer Meteorol 140(1):23-35

Miller SJ, Gordon, M, Staebler RM, Taylor PA (2019) A study of the spatial variation of vehicle-induced turbulence on highways using measurements from a mobile platform. Boundary-Layer Meteorol 171(1):1-29

\section{Mahrt}

Mahrt LJ, Schwerdtfeger W (1970) Ekman spirals for exponential thermal wind. BoundaryLayer Meteorol 1(2):137-145

Mahrt L, Heald RC, Lenschow DH, Stankov BB, Troen IB (1979) An observational study of the structure of the nocturnal boundary layer. Boundary-Layer Meteorol 17(2):247-264 Mahrt L (1981) Modelling the depth of the stable boundary layer. Boundary-Layer Meteorol 21(1): 3-19

Mahrt L, Pan H (1984) A two-layer model of soil hydrology. Boundary-Layer Meteorol 29(1):1-20

Mahrt L, Paumier J (1985) Simple formulation of heat flux in the unstable atmospheric boundary layer. Boundary-Layer Meteorol 33(1):61-75

Troen I, Mahrt L (1986) A simple model of the atmospheric boundary layer; sensitivity to surface evaporation. Boundary-Layer Meteorol 37(1-2):129-148

Pan HL and Mahrt L (1987) Interaction between soil hydrology and boundary-layer development. Boundary-Layer Meteorol 38(1-2):185-202

Ruscher P, Mahrt L (1989) Coherent structures in the very stable atmospheric boundary layer. Boundary-Layer Meteorol 47(1-4):41-54

Mahrt L, Larsen S (1990) Relation of slope winds to the ambient flow over gentle terrain. Boundary-Layer Meteorol 53(1-2):93-102

Mahrt L, Gibson W (1992) Flux decomposition into coherent structures. Boundary-Layer Meteorol 60(1-2):143-168

Mahrt L, Ek M (1993) Spatial variability of turbulent fluxes and roughness lengths in HAPEX-MOBILHY. Boundary-Layer Meteorol 65(4):381-400

Mahrt L, MacPherson I, Desjardins R (1994) Observations of fluxes over heterogeneous surfaces. Boundary-Layer Meteorol 67(4):345-367

Frech M, Mahrt L (1995) A two-scale mixing formulation for the atmospheric boundary layer. Boundary-Layer Meteorol 73(1-2):91-104

Sun J, Mahrt L (1995) Relationship of surface heat flux to microscale temperature variations: application to BOREAS. Boundary-Layer Meteorol 76(3):291-301

Mahrt L (1996) The bulk aerodynamic formulation over heterogeneous surfaces. Boundary-Layer Meteorol 78(1-2):87-199

Howell JF, Mahrt L (1997) Multiresolution flux decomposition. Boundary-Layer Meteorol 83(1):117-137

Vickers D, Mahrt L (1997) Fetch limited drag coefficients. Boundary-Layer Meteorol 85(1):53-79

Mahrt L, Vickers D, Edson J, Sun J, Højstrup J, Hare J, Wilczak JM (1998) Heat flux in the coastal zone. Boundary-Layer Meteorol 86(3):421-446 
Mahrt L (1998) Nocturnal boundary-layer regimes. Boundary-Layer Meteorol 88(2):255-278

Mahrt L (1999) Stratified atmospheric boundary layers. Boundary-Layer Meteorol 90(3):375-396

Mahrt L (2000) Surface heterogeneity and vertical structure of the boundary layer. Boundary-Layer Meteorol 96(1-2):33-62

Mahrt L, Vickers D, Sun J, Jensen NO, Jørgensen H, Pardyjak E, Fernando H (2001) Determination of the surface drag coefficient. Boundary-Layer Meteorol 99(2):249-276

Mahrt L, Vickers D, Edson J, Wilczak JM, Hare J, Højstrup J (2001) Vertical structure of turbulence in offshore flow during RASEX. Boundary-Layer Meteorol 100(1):47-61

Mahrt L, Vickers D, Nakamura R, Soler MR, Sun J, Burns S, Lenschow DH (2001) Shallow drainage flows. Boundary-Layer Meteorol 101(2):243-260

Soler MR, Infante C, Buenestado P, Mahrt L (2002) Observations of nocturnal drainage flow in a shallow gully. Boundary-Layer Meteorol 105(2):253-273

Mahrt L, D Vickers (2002) Contrasting vertical structures of nocturnal boundary layers. Boundary-Layer Meteorol 105(2):351-363

Klipp C, Mahrt L (2003) Conditional analysis of an internal boundary layer. BoundaryLayer Meteorol 108(1):1-17

Mahrt L, Vickers D (2004) Bulk formulations of the surface heat flux. Boundary-Layer Meteorol 110(3):357-379

Mahrt L, Vickers D, Moore E (2004) Flow adjustments across sea-surface temperature changes. Boundary-Layer Meteorol 111(3):553-564

Nakamura R, Mahrt L (2005) A study of intermittent turbulence with CASES-99 tower measurements. Boundary-Layer Meteorol 114(2):367-387

Mahrt L, Vickers D (2005) Boundary-layer adjustment over small-scale changes of surface heat flux. Boundary-Layer Meteorol 116(2):313-330

Vickers D, Mahrt L (2006) A solution for flux contamination by mesoscale motions with very weak turbulence. Boundary-Layer Meteorol 118(3):431-447

Mahrt L, Vickers D (2006) Extremely weak mixing in stable conditions. Boundary-Layer Meteorol 119(1):19-39

Skyllingstad ED, Vickers D, Mahrt L, Samelson R (2007) Effects of mesoscale sea-surface temperature fronts on the marine atmospheric boundary layer. Boundary-Layer Meteorol 123(2):219-237

Mahrt L (2007) The influence of nonstationarity on the turbulent flux-gradient relationship for stable stratification. Boundary-Layer Meteorol 125(2):245-264

Mahrt L (2008) The influence of transient flow distortion on turbulence in stable weak-wind conditions. Boundary-Layer Meteorol 127(1):1-16

Mahrt L (2009) Characteristics of submeso winds in the stable boundary layer. BoundaryLayer Meteorol 130(1):1-14

Mahrt L (2010) Variability and maintenance of turbulence in the very stable boundary layer. Boundary-Layer Meteorol 135(1):1-18

Acevedo OC, Mahrt L (2010) Systematic vertical variation of mesoscale fluxes in the nocturnal boundary layer. Boundary-Layer Meteorol 135(1):19-30

Mahrt L (2011) The near-calm stable boundary layer. Boundary-Layer Meteorol 140(3):343-360

Mahrt L, Thomas C, Richardson S, Seaman N, Stauffer D, Zeeman M (2013) Nonstationary generation of weak turbulence for very stable and weak-wind conditions. Boundary-Layer Meteorol 147(2):179-199 
Mahrt L, Sun J, Stauffer D (2015) Dependence of turbulent velocities on wind speed and stratification. Boundary-Layer Meteorol 155(1):55-71

Geiss A, Mahrt L (2015) Decomposition of spatial structure of nocturnal flow over gentle terrain. Boundary-Layer Meteorol 156(3):337-347

Mahrt L, Thomas CK (2016) Surface stress with non-stationary weak winds and stable stratification. Boundary-Layer Meteorol 159(1):3-21

Sun J, Lenschow DH, LeMone MA, Mahrt L (2016) The role of large-coherent-eddy transport in the atmospheric surface layer based on CASES-99 observations. BoundaryLayer Meteorol 160(1):83-111

Mahrt L (2016) Stably stratified flow in a shallow valley. Boundary-Layer Meteorol 162(1):1-20

Mahrt L (2017a) Heat flux in the strong-wind nocturnal boundary layer. Boundary-Layer Meteorol 163(2):161-177

Mahrt L (2017b) Directional shear in the nocturnal atmospheric surface layer. BoundaryLayer Meteorol 165(1):1-7

Mahrt L, Thomas CK, Grachev AA, Persson POG (2018) Near-surface vertical flux divergence in the stable boundary layer. Boundary-Layer Meteorol 169(3):373-393

Mahrt L, Pfister L, Thomas CK (2019) Small-scale variability in the nocturnal boundary layer. Boundary-Layer Meteorol 174(1):81-98

\section{JJ Finnigan and MR Raupach}

Seginer I, Mulhearn PJ, Bradley EF, Finnigan JJ (1976) Turbulent flow in a model plant canopy. Boundary-Layer Meteorol 10(4):423-453

Mulhearn PJ, Finnigan JJ (1978) Turbulent flow over a very rough, random surface. Boundary-Layer Meteorol 15(1):109-132

Finnigan JJ, Mulhearn PJ (1978) Modelling waving crops in a wind tunnel. BoundaryLayer Meteorol 14(2):253-277

Finnigan JJ, Mulhearn PJ (1978) A simple mathematical model of airflow in waving plant canopies. Boundary-Layer Meteorol 14(3):415-431

Finnigan JJ (1979) Turbulence in waving wheat: I. mean statistics and honami. BoundaryLayer Meteorol 16(3):181-211

Finnigan JJ (1979) Turbulence in waving wheat: II. structure of momentum transfer. Boundary-Layer Meteorol 16(3):213-236

Raupach MR (1979) Anomalies in flux-gradient relationships over forest. Boundary-Layer Meteorol 16(4):467-486

Raupach MR, Thom AS, Edwards I (1980) A wind-tunnel study of turbulent flow close to regularly arrayed rough surfaces. Boundary-Layer Meteorol 18(4):373-397

Raupach MR, Shaw RH (1982) Averaging procedures for flow within vegetation canopies. Boundary-Layer Meteorol 22(1):79-90

Legg BJ, Raupach MR (1982) Markov-chain simulation of particle dispersion in inhomogeneous flows: the mean drift velocity induced by a gradient in Eulerian velocity variance. Boundary-Layer Meteorol 24(1):3-13

Raupach MR (1983) Near-field dispersion from instantaneous sources in the surface layer. Boundary-Layer Meteorol 27(2):105-113

Raupach MR, Coppin PA, Legg BJ (1986) Experiments on scalar dispersion within a model plant canopy part I: the turbulence structure. Boundary-Layer Meteorol 35(1-2):21-52

Coppin PA, Raupach MR, Legg BJ (1986) Experiments on scalar dispersion within a model plant canopy part II: an elevated plane source. Boundary-Layer Meteorol 35(1-2):167-191 
Legg BJ, Raupach MR, Coppin PA (1986) Experiments on scalar dispersion within a model plant canopy, part III: an elevated line source. Boundary-Layer Meteorol 35(3):277-302 Finnigan JJ, Raupach MR, Bradley EF, Aldis GK (1990) A wind tunnel study of turbulent flow over a two-dimensional ridge. Boundary-Layer Meteorol 50(1-4):227-317

Raupach MR (1992) Drag and Drag Partition on Rough Surfaces. Boundary-Layer Meteorol 60(4) 375-395

Antonia RA, Raupach MR (1993) Spectral scaling in a high Reynolds number laboratory boundary layer. Boundary-Layer Meteorol 65:289-306

Brunet Y, Finnigan JJ, Raupach MR (1994) A wind tunnel study of air flow in waving wheat: single-point velocity statistics. Boundary-Layer Meteorol 70(1-2):95-132

Coppin PA, Bradley EF, Finnigan JJ (1994) Measurements of flow over an elongated ridge and its thermal stability dependence: the mean field. Boundary-Layer Meteorol 69(1-2):173-199

Raupach MR (1994) Simplified expressions of vegetation roughness length and zero-plane displacement as functions of canopy height and area index. Boundary-Layer Meteorol 71(1-2):211-216

Shaw RH, Brunet Y, Finnigan JJ, Raupach MR (1995) A wind tunnel study of air flow in waving wheat: two-point velocity statistics. Boundary-Layer Meteorol 76(4):349-376

Raupach MR, Finnigan JJ, Brunet Y (1996) Coherent eddies and turbulence in vegetation canopies: the mixing-layer analogy. Boundary-Layer Meteorol 78(3-4):351-382 ${ }^{1}$

Judd MJ, Raupach MR, Finnigan JJ (1996) A wind tunnel study of turbulent flow around single and multiple windbreaks, part 1: velocity fields. Boundary-Layer Meteorol 80(1-2):127-165

Patton EG, Shaw RH, Judd MJ, Raupach MR (1998) Large-eddy simulation of windbreak flow. Boundary-Layer Meteorol 87(2):257-307

Ayotte KW, Finnigan JJ, Raupach MR (1999) A second-order closure for neutrally stratified vegetative canopy flows. Boundary-Layer Meteorol 90(2):189-216

Finnigan JJ (1999) A note on wave-turbulence interaction and the possibility of scaling the very stable boundary layer. Boundary-Layer Meteorol 90(3): 529-539

Finnigan JJ, Shaw RH (2000) A wind-tunnel study of airflow in waving wheat: an EOF analysis of the structure of large-eddy motion. Boundary-Layer Meteorol 96(1-2): 221-225

Baldocchi D, Finnigan J, Wilson K, Paw U KT, Falge E (2000) On measuring net ecosystem carbon exchange over tall vegetation on complex terrain. Boundary-Layer Meteorol 96(1-2):257-291

Raupach MR (2000) Equilibrium Evaporation and the convective boundary layer. Boundary-Layer Meteorol 96(1-2):107-142

Finnigan JJ, Clement R, Malhi Y, Leuning R, Cleugh HA (2003) A re-evaluation of longterm flux measurement techniques part I: averaging and coordinate rotation. BoundaryLayer Meteorol 107(1) 1-48

Cleugh HA, Raupach MR, Briggs PR, Coppin PA (2004) Regional-scale heat and water vapour fluxes in an agricultural landscape: an evaluation of CBL budget methods at OASIS. Boundary-Layer Meteorol 110(1):99-137

Finnigan JJ (2004) A re-evaluation of long-term flux measurement techniques part II: coordinate systems. Boundary-Layer Meteorol 113(1): 1-41

Leuning R, Raupach MR, Coppin PA, Cleugh HA, Isaac P, Denmead OT, Dunin FX, Zegelin S, Hacker S (2004) Spatial and temporal variations in fluxes of energy, water vapour and carbon dioxide during OASIS 1994 and 1995. Boundary-Layer Meteorol 110(1):3-38

1 This paper is reprinted in BLM as a chapter in the 25th Anniversary Volume, pp 351-382. 
Katul G, Poggi D, Cava D, Finnigan J (2006) The relative importance of ejections and sweeps to momentum transfer in the atmospheric boundary layer. Boundary-Layer Meteorol 120(3): 367-375

Katul GG, Finnigan JJ, Poggi D, Leuning R, Belcher SE (2006) The influence of hilly terrain on canopy-atmosphere carbon dioxide exchange. Boundary-Layer Meteorol 118(1):189-216

Raupach MR, Hughes DE, Cleugh HA (2006) Momentum absorption in rough-wall boundary layers with sparse roughness elements in random and clustered distributions. Boundary-Layer Meteorol 120(2):201-218

Yang B, Raupach MR, Shaw RH, Paw U KT, Morse AP (2006) Large-eddy simulation of turbulent flow across a forest edge part I: flow statistics. Boundary-Layer Meteorol 120(3):377-412

Harman IN, Finnigan JJ (2007) A simple unified theory for flow in the canopy and roughness sublayer. Boundary-Layer Meteorol 123(2):339-363

Harman IN, Finnigan JJ (2008) Scalar concentration profiles in the canopy and roughness sublayer. Boundary-Layer Meteorol 129(3) 323-351

Harman IN, Finnigan JJ (2010) Flow over hills covered by a plant canopy: extension to generalised two-dimensional topography. Boundary-Layer Meteorol 135(1):51-65

Harverd V, Böhm M, Raupach MR (2010) The effect of source distribution on bulk scalar transfer between a rough land surface and the atmosphere. Boundary-Layer Meteorol 135(3):351-368

Böhm M, Finnigan JJ, Raupach MR, Hughes D (2013) Turbulence structure within and above a canopy of bluff elements. Boundary-Layer Meteorol 146(3):393-419

Harman IN, Finnigan JJ (2013) Flow over a narrow ridge covered with a plant canopy: a comparison between wind-tunnel observations and linear theory. Boundary-Layer Meteorol 147(1):1-20

Harman IN, Böhm M, Finnigan JJ, Hughes D (2016) Spatial variability of the flow and turbulence within a model canopy. Boundary-Layer Meteorol 160(3):375-396

Poëtte C, Gardiner B, Dupont S, Harman I, Böhm M, Finnigan J, Hughes D, Brunet Y (2017) The impact of landscape fragmentation on atmospheric flow: a wind-tunnel study. Boundary-Layer Meteorol 163(3):393-421

Publisher's Note Springer Nature remains neutral with regard to jurisdictional claims in published maps and institutional affiliations. 